\title{
METODE PENAFSIRAN IBNU AL-QAYYIM AL-JAUZIYYAH
}

\author{
Hafizzullah \\ Dosen Institut Agama Islam Negeri (IAIN) Batusangkar \\ (hafizullah@iainbatusangkar.ac.id)
}

\begin{abstract}
Abstrak
Ibnu Al-Qayyim Al-Jauziyyah merupakan salah seorang ulama abad ke-7 yang dikenal memiliki kemampuan berbagai ilmu dan tumbuh menjadi ulama yang produktif. Salah satunya adalah hasil pemikirannya terhadap penafsiran al-Quran. Namun penafsiranya tidak dituliskan secara terpisah dan utuh, dan hanya ditemukan dalam tulisan-tulisannya yang tersebar dari berbagai kitab. Pengumpulan penafsiran Ibnu Al-Qayyim yang diambil dari berbagai kitab ini telah dilakukan oleh Muhammad Uwais al Nadwiy dalam Tafsir al-Qayyim, yang kemudian disempurnakan oleh Yusri Al-Sayyid Muhammad dalam Badâi' al Tafsir. Dalam penelitian ini, akan dibahas tentang metode dan corak pemikiran Ibnu Al-Qayyim dalam menafsirkan alQuran. Penelitian ini menggunakan metode penelitian pustaka (library research) dengan menela'ah kitab Tafsir al-Qayyim dan Badâi' al Tafsir. Dari hasil penelitian, dapat disimpulkan bahwa dalam menafsirkan Al-Quran, Ibnu Al-Qayyim menerapkan berbagai metode dalam menafsirkan al-Quran, seperti maudhồ'i, tahlîli dan muqâran.
\end{abstract}

Kata Kunci: Tafsir Al-Qayyim, Badâi' Al-Tafsir, Corak, Maudhû'i, Tahlîli dan Muqâran.

\section{Pendahuluan}

Kebutuhan ummat Islam untuk memahami Islam menjadi landasan utama adanya usaha penafsiran alQur'an dari sejak zaman Rasulullah saw hingga sekarang. Berbagai jenis tafsir telah lahir pada medan keilmuan mengikuti alur pemikiran yang berkembang saat masing-masing penafsir memulai debut ilmiahnya dalam kancah penafsiran.

Pada abad ke-7 misalnya, Ibnu Al-Qayyim ikut meramaikan kancah penafsiran dengan menuliskan beberapa aspek terkait dengan beberapa ayat al-Qur'an yang dikemudian hari dikumpulkan dalam sebuah buku dengan nama Al-Tafsir Al-Qayyim oleh Uwais An-Nadawi, salah seorang pecinta karya-karya Ibnu Al-Qayyim, yang kemudian disempurnakan oleh Yusri Al Sayyid Muhammad dalam kitab yang diberi judul Badâi' Al Tafsîr Limâ Fassarah Al Imâm Ibn Qayyim Al Jauziyah. 
Ibn al Qayyim menyampaikan tafsir al-Qur'an yang tersebar dalam beberapa karyanya (karena ia tidak menulis secara khusus dalam satu buku tafsir) dan jika diamati, tafsir-tafsirnya itu disampaikan melalui deskripsi yang sangat detail serta bahasa yang sangat elegan yang secara umum meluapkan semangat pembaharuan, cendrung merespon serta memberikan reaksi atas realitas sosio-historis umat Islam.

\section{Pembahasan}

$$
\begin{aligned}
& \text { 1. Biografi Ibn Al-Qayyim Al- } \\
& \text { Jauziyyah }^{1} \\
& \text { محمد بن أبي بكر بن أيوب بن سعد بن } \\
& \text { حريز بن مكي زيد الدين الزرعي الدمشقي } \\
& \text { الحنبلي الشهير بشمس الدين، أبو عبد الله } \\
& \text { وابن القيم الجوزية }
\end{aligned}
$$

Nama lengkap Ibn al-Qayyim adalah Muhammad bin Abi Bakr ibn Ayyub ibn Sa'ad ibn Hariz bin Makiy Zaiduddin al-Zur'i al-Dimasyqi Al Hanbali, yang terkenal dengan Syams al-Din Abu Abdillah dan Ibnu AlQayyim Al Jauziyah. Beliau lahir di desa Azra, Damaskus pada tanggal 7 Shafar 691 H., bertepatan dengan tahun 1292 M. Ibnu al-Qayyim hidup selama 60 tahun, dan meninggal pada tanggal 13 Rajab 751 H., bertepatan dengan tahun 1350 M. Ibn Al-Qayyim alJauziyyah wafat di Damaskus.

Ibn al-Qayyim berasal dari keluarga yang religius serta cinta ilmu. Ia kemudian tumbuh dewasa dan menjadi terkenal sebagai seorang yang sangat alim, penulis produktif, rendah hati dan taat beribadah. Sehingga sebagian ulama cenderung menilainya

1 Shalahuddin Khalil bin Ubaik al Shafadi, 1998, A'yân al 'Ashri wa A'wân al Nashri, (Beirut: Dâr al Fikr), juz 4, hlm. 366 sebagai seorang sufi yang shaleh. Dalam berbagai tulisannya beliau memperlihatkan akhlak keulamaaan yang tinggi dengan kecintaannya yang meluap-luap terhadap kebenaran dan ketawadhuannya yang semakin membuktikan kualitas, integritas serta otoritasnya sebagai seorang ulama.

Pendidikan Ibn al-Qayim alJauziyyah dimulai dan terutama dibimbing oleh banyak ulama Hanabilah terkemuka di madrasah yang dikelolah oleh ayahnya sendiri, Abu Bakr Ibn Ayyub al-Zur'i, yaitu Madrasah al-Jauziyah. Madrasah yang bertempat di al-Buzuriyyah, Damsyik dan menjadi pusat pendidikan Islam mazhab Hanbali yang didirikan oleh Muhy al-Din Yusuf ibn Abi alFarj Abd al-Rahman ibn Ali ibn Muhammad ibn Ali ibn Ubaidillah ibn al-Jawzi al-Qarsyi al-Bakri alBaghdadi al-Hanbali.

Ibnu Al-Qayyim memiliki banyak guru, di antaranya adalah Ayahnya sendiri (Abu Bakr ibn Ayyub al-Zur'i), Ibnu Taimiyah, Ahmad bin Abdul Dâim Al Maqdisiy, Badr al Din ibn Jama'ah, Al Hafiz Al Zahabi, dan lainnya.

Di antara sekian banyak gurunya, yang banyak mempengaruhi manhaj dan pandangan keagamaan Ibn alQayyim al-Jauziyyah adalah Ibn Taimiyah. Pertemuan dengan gurunya itu terjadi ketika Ibn al-Qayim alJauziyyah mendengar bahwa Ibn Taimiyah pulang dan hendak bermukim lagi di Damaskus, yakni pada tahun $712 \mathrm{H}$, setelah sebelumnya Ibn Taimiyah diusir dari Mesir akibat counter pemikiran yang begitu gencar dilakukannya atas paraktikpraktik tasawuf yang berkembang di Mesir karena dinilainya sebagai bid'ah dhalalah. Sejak itulah Ibn al-Qayim al- 
Jauziyyah bertemu dan menjadi murid Ibn Taimiyah selama kurang lebih dari 16 tahun. Kepada ulama besar yang kemudian menjadi guru tetapnya itulah ia mempelajari berbagai disipilin ilmu, terutama tafsir, hadits, fiqh, fara'id dan ilmu kalam.

Pada masa Ibn al-Qayim, kehidupan Islam juga diwarnai dengan semakin berkembangnya aliran-aliran kongkrit di bidang kalam. Diantara aliran kalam yang paling berpengaruh adalah Mazhab Asy'ariah yang banyak tersebar di Irak dan sekitarnya berkat pemikiran yang diusung oleh alGhazali. Sedangkan di Mesir mazhab ini dikembangkan oleh sultan Shalahuddin al-Ayyubi dan penguasapenguasa dinasti Ayyubiyah berikutnya. Adapun di Maghrib, mazhab ini dikembangkan oleh penguasa Daulah Al-Muwahhidin bernama Muhammad ibn Tumar.

Aliran mazhab lain yang berkembang pada masa Ibn Al-Qayyim al-Jauziyyah adalah Mazhab alRafidhah di Khurasan dan Irak. Di Khurasan pun berkembang mazhab alKaramiyyah. Dan kemudian di Yaman berkembang Mazhab Zaidiyah. Paham keislaman yang mendapat respon serta reaksi keras dari Ibn Al-Qayyim alJauziyyah adalah Jabariah dan Qadariyah. Disamping tersebar dalam tafsirnya, Ibn Al-Qayyim al-Jauziyyah secara khusus menulis buku Syifa' alAlil yang di dalamnya dibahas kritikannya terhadap paham Jabariyah dan Qadariah.

Di samping diwarnai oleh perkembangan di bidang filsafat Islam, terutama filsafat Ibn Sina dan AlFarabi, pada periode ini kehidupan Islam diwarnai pula oleh berkembangnya aliran-aliran Tasawuf, antara lain Tasawuf Falsafi-nya Muhyi
al-Din Ibn Arabi dan Umar Ibn alFarid. Adapun aliran-aliran thariqat yang berkembang pada periode tersebut antara lain: Al-Qadiriyah dari Abdul Qadir al-Jailani, AlSuhrawardiyah oleh Abdul Qadir Syuhrawardi, Al-Rifaiyyah dari Ahmad al-Rifa'i al-Husaini, $A l$ Dasuqiyyah dari Ibrahim al-Dasuqi, $A l$ Mawawiyah dari Jalaluddin Rumi, AlAkbariyah dari Muhy al-Din ibn alArabi, Al-Syadzaliyah dari Abul Hasan al-Syadzili dan thariqat alNaqsyabandiah dari Muhammad ibn Baha'u al-Din Naqsyaband.

Sebagai seorang ulama yang terpandang, Ibnu al-Qayyim memiliki banyak murid. Di antara muridmuridnya adalah: Al Hafiz Ibn Katsir, Ahmad bin Abdul Hadi bin Qudamah al Maqdisy, Muhammad bin Ya'qub bin Muhammad Fairuz Abadi, Burhan bin Al Qayyim AL Jauziyah (putranya), dan lainnya.

Ibn al-Qayyim menulis banyak buku. Tidak kurang dari 66 buku telah lahir dari kepiawaiannya dalam ilmuilmu keislaman. Secara umum karyakarya tersebut menebarkan spirit pembaharuan guna merespon dan memberikan reaksi terhadap keadaan umat Islam yang berlangsung sepanjang kekuasaan Mamluk. Di antara karya Ibnu Al-Qayyim Al Jauziyah adalah:

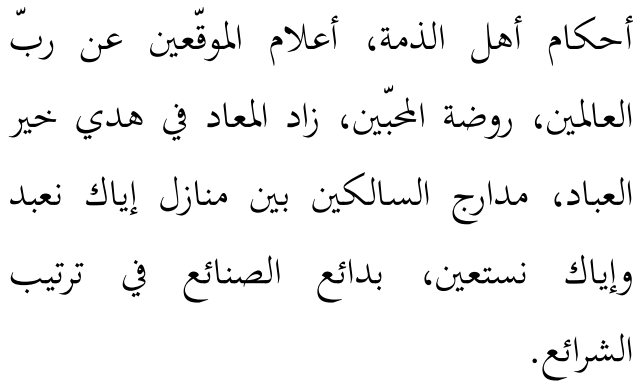

Keterangan lebih lanjut tentang biografi Ibn Al Qayyim Al Jauziyah ini 
dapat dilihat dalam kitab Al Bidâyah wa Al Nihâyah yang dikarang muridnya sendiri, yaitu Ibnu Katsir. ${ }^{2}$

\section{Tafsir Ibn Al-Qayyim Al- Jauziyyah \\ a) Sekilas tentang Tafsir Ibnu Al- Qayyim}

Judul Kitab: بدائع التفسير لما فسره الإمام

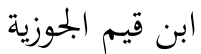

Pengarang: Al Imam Al Hafiz Syamsuddin Ibn Al Qayyim

Kelahiran: Lahir tahun $691 \mathrm{H} / 1292 \mathrm{M}$, wafat tahun $751 \mathrm{H} / 1350 \mathrm{M}$

Penyusun : بسري السيد محمد :

Pada cetakan Dâr Ibn Jauzi, kitab tafsir ini terdiri dari 3 jilid. Badâi' al Tafsir ini merupakan tafsir ayat-ayat pilihan yang dituliskan oleh Ibnu AlQayyim al Jauziyah dalam berbagai kitabnya. Berbagai penafsiran ini diambil dari sekian banyak karya Ibnu Al-Qayyim, yang tentu saja berkaitan dengan penafsiran Al Quran ketika beliau sedang mengupas tentang berbagai masalah. Kemudian tafsirtafsir ini dikumpulkan dan disusun secara berurutan menurut urutan dalam Al Quran, surat dan ayat-ayatnya.

Kitab tafsir ini pada dasarnya bukanlah karya Ibnu Al-Qayyim sendiri, karena Ibnu Al-Qayyim tidak pernah menulis kitab tafsir, akan tetapi beliau pernah bercita-cita untuk menulis sebuah kitab tafsir. ${ }^{3}$ Kitab ini dikumpulkan oleh Yusri Al Sayyid Muhammad, yang mana sebelumnya telah dirintis oleh Muhammad Uwais al

${ }^{2}$ Al Hafiz Ibn Katsir, 1986, Al Bidâyah wa Al Nihâyah, (Beirut: Dâr Al Fikr), juz 14, hlm. 234

${ }^{3}$ Ibnu Qayyim Al Jauziyah, t.th., Badâi' al Fawâid, (Beirut: Dâr Al Kitab Al 'Arabiy), Juz 1, hlm. 141
Nadwi, seorang ulama muhaqqiq yang berasal dari India, seorang pecinta karya Ibnu Al-Qayyim dengan kitab yang sangat ringkas dan belum mencakup seluruh tafsir al Quran yang diberi nama "Al Tafsir Al Qayyim".

Kitab ini tidak mencakup seluruh penafsiran ayat al Quran dikarenakan kitab ini bukanlah merupakan tulisan yang sejak awal dimaksudkan sebagai kitab tafsir, maka cukup banyak ayatayat yang dilompati dan sama sekali tidak disinggung, dan bahkan ada beberapa surat yang sedikitpun di antara ayat-ayatnya tidak disentuh penafsirannya. Kitab ini mencakup 109 surat. Adapun surat yang tidak ditafsirkan dalam kitab ini adalah surat Al Qadr, Al Qari'ah, Al Fil, Quraisy dan Al Kautsar.

Jadi, pada dasarnya kitab ini bukanlah karya Ibnu Al-Qayyim langsung, melainkan kitab ini berisikan tafsir ayat-ayat pilihan yang dihimpun oleh Muhammad Uwais al Nadwiy yang ia temukan dalam karya-karya Ibnu Al-Qayyim, yang kemudian penafsiran al Quran yang dia temukan dalam karya-karya tersebut dia kumpulkan ke dalam sebuah kitab. Dikarenakan penafsiran yang dia kumpulkan tersebut murni berasal dari Ibnu Al-Qayyim, maka kitab ini dia beri nama "التفسير القيم للإمام ابن القيم", yang dikemudian hari disempurnakan oleh Yusri Al Sayyid Muhammad dalam بدitab yang diberi nama “ بلدائع التفسير لما

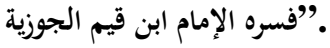

b) Kitab-kitab Sumber

Sebagaimana yang telah dijelaskan di atas, bahwa kitab tafsir ini merupakan kumpulan-kumpulan tafsir yang tersebar dalam kitab-kitab Ibnu Al-Qayyim. Adapun kitab-kitab yang 
dijadikan sumber oleh Yusri Al Sayyid Muhammad dalam mengumpulkan tafsir Ibnu Al-Qayyim ini berjumlah 32 kitab, diantaranya adalah: ${ }^{4}$ Ijtima' $A l$ Juyusy Al Islamiy, kitab inilah yang dijadikan standar bagi Yusri Al Sayyid Muhammad dalam mengumpulkan tafsir Ibnu Al-Qayyim, Madârij Al Sâlikîn, yang menjadi rujukan utama tafsir surat Al Fatihah. Ahkam Ahlu Al Zimmah, Asmâ Muallafât Ibn Taimiyah, Syifâ al 'Alîl, Al Wâbil Al Shayyib, Hâdi al Arwâh, Jalâ al Afhâm, Badâi' al Fawâid, I'lâm al Muwaqqi'în, Miftâh Dâr al Sa'âdah, Tuhfah al Wadûd, Tharîq al Hijratain, Al Jawâb al Kâfi, Al Shawâi' al Mursalah, Raudhah al Muhibbîn, Ighâstah al Lahafân, Al Tibyân fi Ahkâm al Qurani, Zâd al Ma'âd, 'Iddah al Shâbirîn, dan lain-lain

c) Langkah-langkah dan Metode Ibnu Al-Qayyim dalam menafsirkan $\mathrm{Al}$ Quran

Ibnu Al-Qayyim tidak menjelaskan secara langsung tentang metode yang diterapkan dalam menafsirkan ayat-ayat al-Quran dalam berbagai karyanya. Namun dari berbagai bentuk penafsirannya, dapat dipahami bahwa ketika Ibnu AlQayyim dalam menafsirkan Al Quran terlebih dahulu dengan memaparkan sebuah ayat, kemudian ayat tersebut ditafsirkan dengan penafsiran Tahlili, dengan arti kata, suatu ayat yang pada satu tempat ditafsirkan secara mujmal, maka pada tempat lain ayat tersebut ditafsirkan secara terperinci, dan jika pada satu tempat ayat tersebut ditafsirkan secara ringkas, maka pada

${ }^{4}$ Yusri Al Sayyid Muhammad, 1427 H, Badâi' al Tafsir, (Saudi: Dâr Ibn Jauziyah), Juz 1, hlm. 14 tempat lain akan ditafsirkan secara panjang. ${ }^{5}$

Ditinjau dari sumber penafsirannya, dapat dikatakan bahwa Ibn al-Qayyim tidak mengambil sumber tafsir kecuali tafsir yang bersumberkan pada nash al-Qur'an dan al-Sunnah, atau pada riwayat-riwayat yang datang baik dari kalangan sahabat, tâbi'in maupun tâbi' tâbi'in, yang dikenal dengan al tafsir bi al ma'tsur. Hanya saja sulit bagi penulis untuk mengkaji metode apa yang secara konsisten yang dipergunakan oleh Ibn al-Qayyim dalam manafsirkan al-Qur'an. Mengingat empat metode tafsir terkenal (seperti metode tahlili, ijmâli, muqâran dan maudhu'i) yang sering diidentifikasi para ahli tafsir alQur'an, semuanya tidak bisa dipergunakan secara konsisten untuk mengkategorisasi metode tafsir Ibn alQayyim.

Pada beberapa tempat Ibn alQayyim menafsirkan al-Qur'an dengan metode tahlîli, tetapi pada tempat lainnya beliau menggunakan metode ijmâli dan muqâran. Hal ini disebabkan karena tafsir yang dikumpulkan oleh Muhammad Uwais ini berasal dari kitab Ibnu Al-Qayyim yang berbedabeda dan topik yang juga berbeda, sehingga metode yang digunakan dalam penafsiran ini juga beragam.

1) Metode Tahlili

Bentuk metode tahlili ini dapat diketahui dari langkah-langkah penafsirannya, jika penafsiran sebuah ayat dibagi ke dalam beberapa fashal, maka surat tersebut dapat dikategorikan ke dalam penafsiran tahlili. Diantara surat-surat yang ditafsirkan dengan

5 Muhammad Ali Ayazi, t.th., Al Mufassirun Hayatuhum wa Manhajuhum, (Tp: Markaz Tahqiqi 'Ilum Islami), hlm. 187 
metode tahlîli ini adalah surat Al Fatihah, pembahasan mengenai surat ini sangat panjang, bahkan mencapai 100 halaman lebih, beberapa ayat dalam surat $\mathrm{Al}$ Baqarah, surat Al A'raf, surat Al Falaq, surat Al Nas, dan lainnya.

Contoh metode penafsiran ini seperti yang dia lakukan terhadap surat Al Falaq dan Al Nas (al mu'awwidzataini), penafsiran terhadap kedua surat ini cukup panjang, yang mengungkapkan segala aspek yang mungkin dapat dipahami dari surat ini.

Gambaran metode Ibnu AlQayyim tersebut dapat tergambar sebagai berikut:

Langkah awal yang ia lakukan adalah membuat ayat surat al Falaq ini:

قُلْ أَعَوذُ برَبِّ الْفَلَق (1) منْ شَرِّ ما خَلَقَ

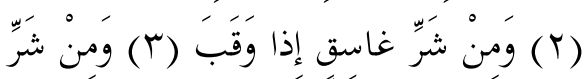

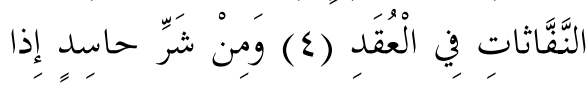

حسد (0)

Setelah itu, Ibnu Al-Qayyim menyertakan beberapa hadis yang mengandung keutamaan surat ini:

روى مسلم في صحيحه من حديث قيس

بن حازم عن عقبة بن عامر قال: قال رسول الله صلّى الله عليه وسلّم الألم تر آيات أنزلت الليلة لم ير مثلهن قط: أعوذ برب الفلق. أعوذ برب الناسه . . وفي الترمذي: حدثنا قتيبة أخبرنا ابن لهيعة عن يزيد بن أبي حبيب عن علي بن رباح عن عقبة بن عامر

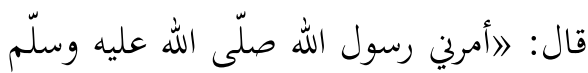
أن أقرأ بالمعوذتين في دبر كل صلاةها
Serta masih ada beberapa hadis lainnya yang berisikan keutamaan kedua surat ini. Setelah menyertakan hadis-hadis tersebut, Ibnu Al-Qayyim menjelaskan maksud dan tujuannya memaparkan hadis-hadis tersebut:

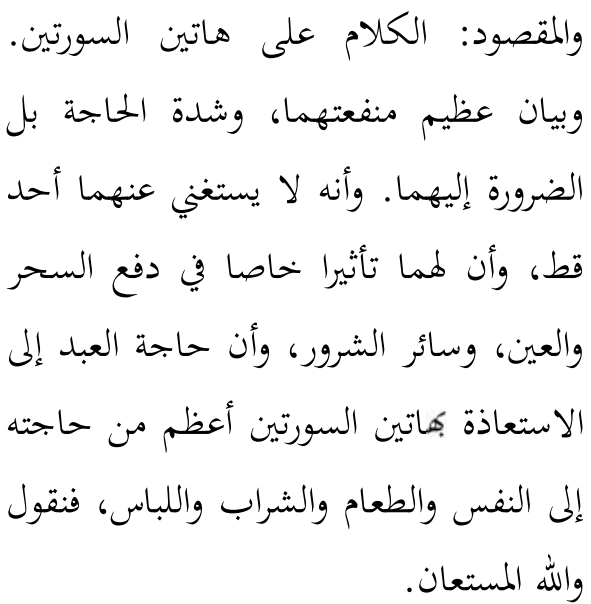

Kemudian Ibnu Al-Qayyim menjelaskan isi kandungan kedua surat ini:

قد اشتملت السورتان على ثلاثة أصول.

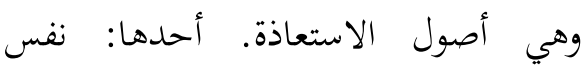
الاستعاذة. و والثانية: المستعاذ به. والثالثة: المستعاذ منه. فبمعرفة ذلك تعرف شدة الحاجة والضرورة إلى هاتين السورتين. فنعقد لمما ثناثة فصول: الفصل الأول: في الاستعاذة. والثاني: في المستعاذ به. والثالث

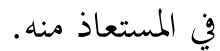

Surat Al Falaq ini dibagi ke dalam 19 fashal, masing-masing fashal tersebut berisikan pembahasan mendalam tentang ketiga fashal di atas dan ditambahkan dengan fashal-fashal yang lainnya, seperti fashal pertama membahas tentang kalimat 
isti'adzah tersebut, yang dimulai dengan pembahasan tentang isti'adzah dari segi bahasa, makna kalimat isti'adzah, cara membaca lafaz isti'adzah dan lain sebagainya. Jadi, satu fashal saja, berisikan satu topik pembahasan, yaitu makna isti'adzah.

الفصل الأول :اعلم أن لفظة 》عاذ《 وما

تصرف منها تدل على التحرز والتحصن

والنجاة. وحقيقة معناها: الهروب من شيء

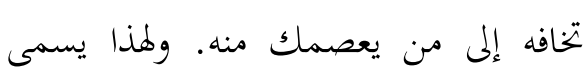

المستعاذ به: معاذا، كما يسمى: ملجأ ووزرا.

Setelah hal tersebut dijelaskan panjang lebar, maka Ibnu AlQayyim menjelaskan cara membaca lafaz isti'adzah:

وأصل هذا الفعل: 》أعوذخ بتسكين العين

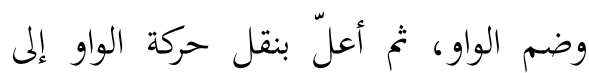
العين وتسكين الواو. فقالوا: أعوذ على أصل هذا الباب، ثم طردوا إعلاله، فقالوا في اسم الفاعل: عائذ. وأصله: عاوذ. فوقعت الواو بعد ألف فاعل، فقلبوها همزة، كما قالوا: قائم، وخحائف. وقالوا في المصدر: عياذا بالله. وأصله: عواذا كلوذ، فقلبوا الواو ياء لكسرة ما قبلها، ولم تحصنها حركتها. لأفما قد ضعفت بإعلالها في العمل.

Pada fashal kedua, berisikan pembahasan rinci tentang kepada siapa ber-isti'adzah tersebut, dan seterusnya.

الفصل الثاني: في المستعاذ. وهو الله وحده،

رب الفلق. ورب الناس، ملك الناس، إله

$$
\begin{aligned}
& \text { الناس. الذي لا ينبغي الاستعاذة إلا به، ولا } \\
& \text { يستعاذ بأحد من خلقه، بل هو الذي يعيذ } \\
& \text { المستعيذين، ويعصمهم. ويمنعهم من شر ما } \\
& \text { استعاذوا من شره. }
\end{aligned}
$$

Begitu juga halnya dengan fushul-fushul yang lainnya, yang masing-masing fushul mendapat porsi pembahasan yang sesuai dengan aspek-aspek yang ingin dikaji. ${ }^{6}$

2) Metode Ijmâli

Metode ijmâli dalam kitab ini dapat diketahui dengan tidak adanya pembagian penafsiran sebuah surat ke dalam fashal-fashal seperti halnya metode tahlîli, dan ayat-ayat dalam surat tersebut tidak ditafsirkan keseluruhannya, melainkan hanya beberapa ayat saja yang ditafsirkan, seperti yang dapat ditemukan dalam penafsiran surat Al Syams ayat 9 dan 10:

$$
\begin{aligned}
& \text { [سورة الشمس: قَدْ أَفْلَحَ مَنْ زَكَّاها (9) وَقَدْ }
\end{aligned}
$$

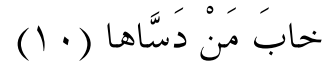

$$
\begin{aligned}
& \text { المعنى: قد أفلح من كبرها وأعلاها بطاعة }
\end{aligned}
$$

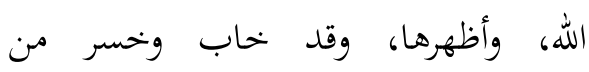

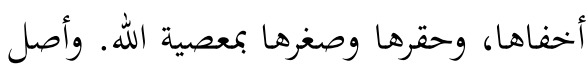

$$
\begin{aligned}
& \text { التدسية: الإخفاء. ومنه قوله تعالى: } 7 \text { إ: }
\end{aligned}
$$

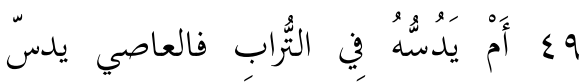

$$
\begin{aligned}
& \text { نفسه بالمعصية، ويخفي مكانها، ويتوارى من لئن } \\
& \text { الخلق من سوء ما يأتي به، قد انقمع عند } \\
& \text { نفسه، وانقمع عند الله، وانقمع عند الخلق. }
\end{aligned}
$$

${ }^{6}$ Muhammad Uwais Al Nadwi, 1410 H., Al Tafsir al Qayyim, (Beirut: Dâr wa Maktab al-Hilâl), hlm. 605 
Ayat di atas langsung ditafsirkan oleh Ibnu Al-Qayyim, tanpa mengkaji bentuk penafsiran dari ulama lain.

3) Metode Muqâran

Metode muqâran yang ditemukan dalam kitab ini tidaklah banyak. Di antaranya seperti penafsiran terhadap surat Al Qiyamah ayat 36:

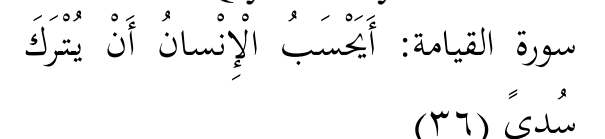

قال الشافعي رضي الله عنه: أي هملا لا يؤمر ولا ينهى? وقال غيره: لا يثاب ولا يعاقب. و والقولان و واحد. لأن الثواب والعقاب غاية الأمر والنهي، فهو سبحانه خلقهم للأمر والنهي في الدنيا، والثواب والعقاب في الآخرة.

Dari contoh di atas, Ibnu AlQayyim tampak membandingkan pendapat Imam Syafi'i dan lainnya mengenai makna ayat tersebut, yang kemudian kedua pendapat tersebut ia satukan.

4) Metode Maudhu'i

Dikarenakan kitab ini merupakan kumpulan penafsiran Ibnu Al-Qayyim yang diambil dari berbagai kitab, maka terkadang penafsiran yang diambil tersebut berasal dari satu buku yang membahas satu permaslahan. Jadi penafsiran yang diambil tersebut berbentuk maudhu'i. Sebagaimana penafsiran yang dilakukan dalam kitab-kitabnya Aqsâm al Quran, Amtsâl Al Quran, al Wâbil Al Shayyib min Al Kalâm al Thayyib, Al Zkru fi Al Quran wa Al Sunnah, Hâdi al Arwâh, AL Jannah fi Al
Quran, dan 'Uddah al Shâbirin wa Dakhirah al Syâkirin.

Keseluruhan kitab-kitab di atas, dipaparkan oleh Ibnu Al-Qayyim secara maudhu'i, yaitu dengan mengambil satu topik permasalahan dalam al Quran, kemudian permasalahan tersebut dibahas secara mendalam, dengan menghubungkan tujuan pokok satu surat dengan surat lainnya yang akan menjadi dasar memahami makna ayat.

Jadi, secara umum kitab ini berisikan multi-metode tafsir. Namun demikian, hal lain yang dilakukan Ibn al-Qayyim ketika manafsirkan alQur'an, selain tafsir ma'tsur adalah:

Pertama, ketika menafsirkan ayat-ayat al-Qur'an yang terkait dengan prinsip-prinsip aqidah, Ibn al-Qayyim selalu berpegang pada makna lahiriah ayat al-Qur'an. Meski demikian, pemahaman tafsirnya sangat luas dan mendalam.

Kedua, ketika menafsirkan ayat yang maknanya mutasyâbihât, Ibn alQayyim senantiasa men-ta'wilkan-nya dengan pendekatan dan caranya sendiri. Ketika menafsirkan kata "ثماهم" Ibn al-Qayyim tidak terjebak pada aspek kebahasaan. Ibn alQayyim tidak mempokuskan perhatiannya pada kata "استوى" sebagaimana halnya banyak dilakukan oleh banyak mufassir. Perhatian Ibn alQayyim justru tecurah pada kata "الرحم".

Segi yang sebenarnya sangat menarik untuk dikaji dari tafsir ibn alQayyim adalah masalah kecendrungan tafsirnya yang sangat khas. Tujuan dan pendekatan tafsirnya cenderung memperlihatkan bahwa dirinya sangat peduli pada kehidupan sosial 
keagamaan umat Islam. Dan karena itu Ibn al-Qayyim hendak menyampaikan tanggapan-tanggapan dan penolakanpenolakan tertentu atas persoalan yang tengah berkembang pada di tengah kehidupan umat Islam pada masa hidupnya.

Dalam hal ini penulis banyak menemukan pendekatan yang dilakukan oleh Ibn al-Qayyim dalam penafsirannya. Ia tidak fokus pada satu pendekatan saja, sehingga tafsir ini menjadi spesial. Namun demikian, dalam tafsir ayat-ayat serta surat-surat tertentu dalam al-Qur'an, misalnya dalam surat al-Fatihah, pendekatan Ibn al-Qayim adalah cenderung teologis. Karena dalam tafsir tersebut Ibn alQayyim memulai pembahasan dengan mengemukakan asumsi-asumsi teologis yang diyakininya.

Hal ini dapat dipahami dari contoh berikut ini:

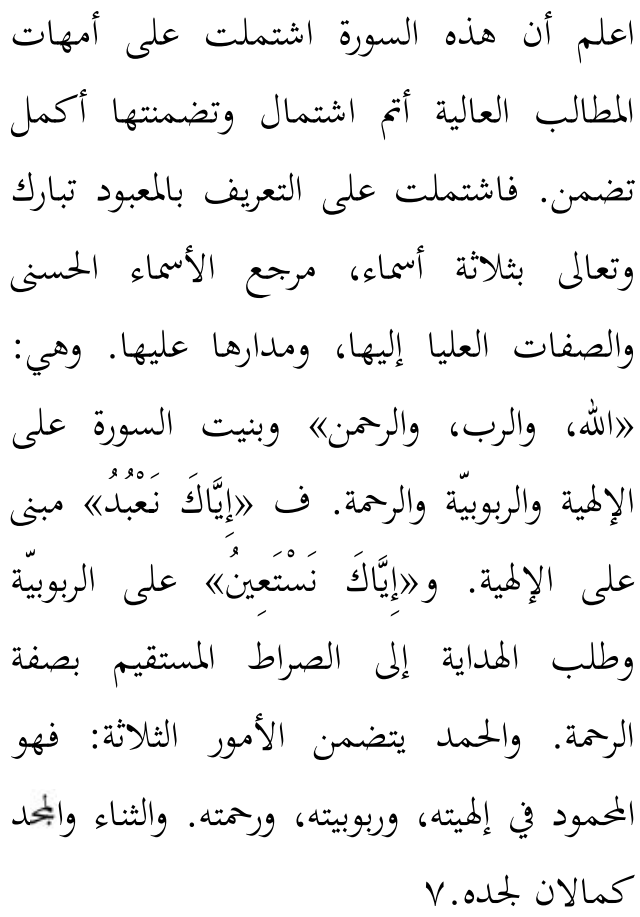

${ }^{7}$ Ibid., hlm. 11
Sekalipun Ibnu Al-Qayyim ahli hukum Islam, namun dalam tafsir ayatayat hukum, pendekatan yang fiqh Ibn al-Qayyim ternyata kurang menonjol. Yang terasa justru pendekatan hikmah hukum atau dikenal dengan "filsafat hukum"nya, hal mana aspek-aspek hukum lebih banyak disorot segi hikmahnya, yaitu hikmah dibalik hukum dan bukan segi hukumnya.

Seperti yang terdapat dalam penafsiran ayat Perang pada surat AlBaqarah: 216:

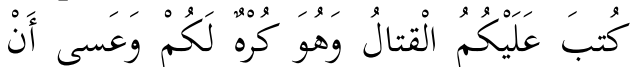

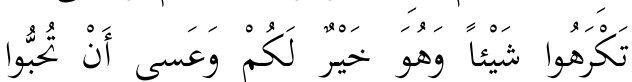

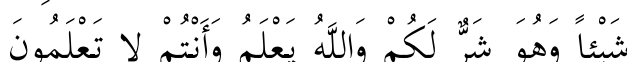

$(Y \backslash 7)$

في هذه الآية عدة حكم وأسرار، ومصالح للعبد. فإن العبد إذا علم أن المكروه قد يأتي

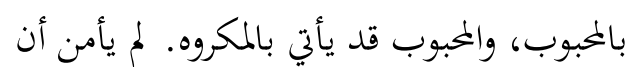
توافيه المضرة من جانب المسرّة، ولم ييأس أن بأن

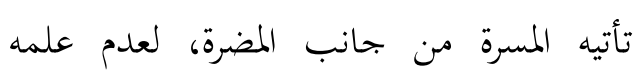

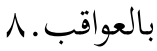

Dalam penafsiran ayat ini, Ibnu Al-Qayyim tidak menjelaskan bagaimana hukum perang melawan musuh Islam, akan tetapi penafsiran ayat ini dimulai dengan mengungkapkan hikmah dari diwajibkannya perang tersebut.

Hal yang sangat terasa disampaikan oleh Ibn al-Qayyim melalui ayat-ayat yang ditafsirkannya adalah bahwa ia sedang merespon bahkan dalam beberapa pendapat tafsir ia menunjukkan reaksinya terhadap pemerintahan, ulama, umat dan sejarah

${ }^{8}$ Ibid., hlm. 147 
islam yang tengah terjadi pada saat itu. Dalam hal ini penulis sampai pada sebuah kesimpulan bahwa dari segi tujuannya tafsir-tafsir (paling tidak sebagian tafsir) Ibn al-Qayyim adalah cendrung responsif dan atau reaktif. Asumsi penulis ini didasarkan pada beberapa indikasi yang dapat dibaca dari tafsir Ibn al-Qayyim yaitu:

1. Adanya unsur penerimaan, persetujuan, atau pembelaan;

2. Adanya unsur perluasan wacana keislaman;

3. Adanya unsur penolakan, ketidaksetujuan atau penentangan yang dikenal dengan istilah counter pemikiran.

Contoh nyata dari ketiga unsur ini dapat dilihat dalam penafsiran surat Ali Imran ayat 18:

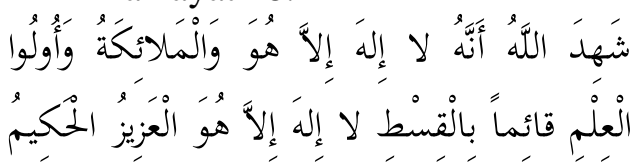

تضمنت هذه الآية الكريمة: إثبات حقيقة

التوحيد، والرد على جميع هذه الطوائف- التي لصني الباته

فصل عقائدها الباطلة قبل هذا- والشهادة

ببطلان أقوالهم، ومذاهبهم. وهذا إنما يتبين بعد

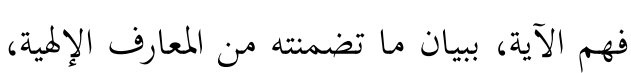

والحقائق الإيمانية.

فتضمنت هذه الآية: أجل شهادة وأعظمها،

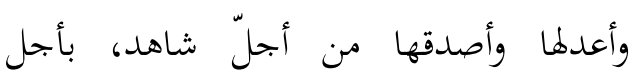

مشهود. وعبارات السلف في 》شهد| تدور

على: الحلكم والقضاء، والإعلام و والبيان

والإخبار. قال بحاهد: حكم وقضى. وقال
الزجاج: بيّ. وقالت طائفة: أعلم وأخبر. وهذه

$$
\text { الأقوال كلها حق، لا تنافي بينها. }
$$

(Inilah bentuk unsur penerimaan, persetujuan, atau pembelaan yang dilakukan Ibnu Al-Qayyim, di antara bentuk unsur tersebut adalah (a) komitmen untuk melandaskan penafsiran hanya pada sumber-sumber yang teriwayatkan (tafsir bi alma'tsur); (b) disampaikan dengan cara pengambilan beberapa sumber tafsir;)

Unsur selanjutnya adalah: Unsur perluasan: yang disampaikan sebagai wujud komitmen pembaharuan umat; dan disampaikan dengan penyampaian argumentasi tafsir maupun berupa wacana keagamaan baru.

Hal ini dapat dibuktikan dari penjelasan yang dilakukan Ibnu AlQayyim:

فإن الشهادة تتضمن كلام الشاهد، وخبره وقوله: وتتضمن إعلامه وإخباره وبيانه. فلها

أربع مراتب: فأول مراتبها: علم ومعرفة، واعتقاد لصحة المشهود به وثبوته. وثانيها: تكلمه بذلك ونطقه به. وإن لم يعلم به غيره، بل يتكلم هو به مع نفسه، ويذكرها وينطق بها، أو يكتبها. وثالثها: أن يعلم غيره بما شهد به، وبخخبه به، ويبينه له. ورابعها: أن يلزمه بمضمونها، ويأمره

فشهادة الله سبحانه لنفسه بالوحدانية، والقيام بالقسط: تضمنت هذه المراتب الأربع: علم الله

${ }^{9}$ Ibid., hlm. 177 


$$
\begin{aligned}
& \text { سبحانه بذلك، وتكلمه به، وإعلامه، وإخباره } \\
& \text { خلقه به، وأمرهم وإلزامهم به. · }
\end{aligned}
$$

Dalam penafsirannya, Ibnu AlQayyim menjelaskan bentuk-bentuk Syahadah yang dapat dipahami dari ayat tersebut, dan ini dinilai sebagai unsur perluasan wacana keislaman.

Adapun unsur terakhir, yaitu unsur penolakan, nampak jelas dari ungkapan Ibnu Al-Qayyim sebagai berikut:

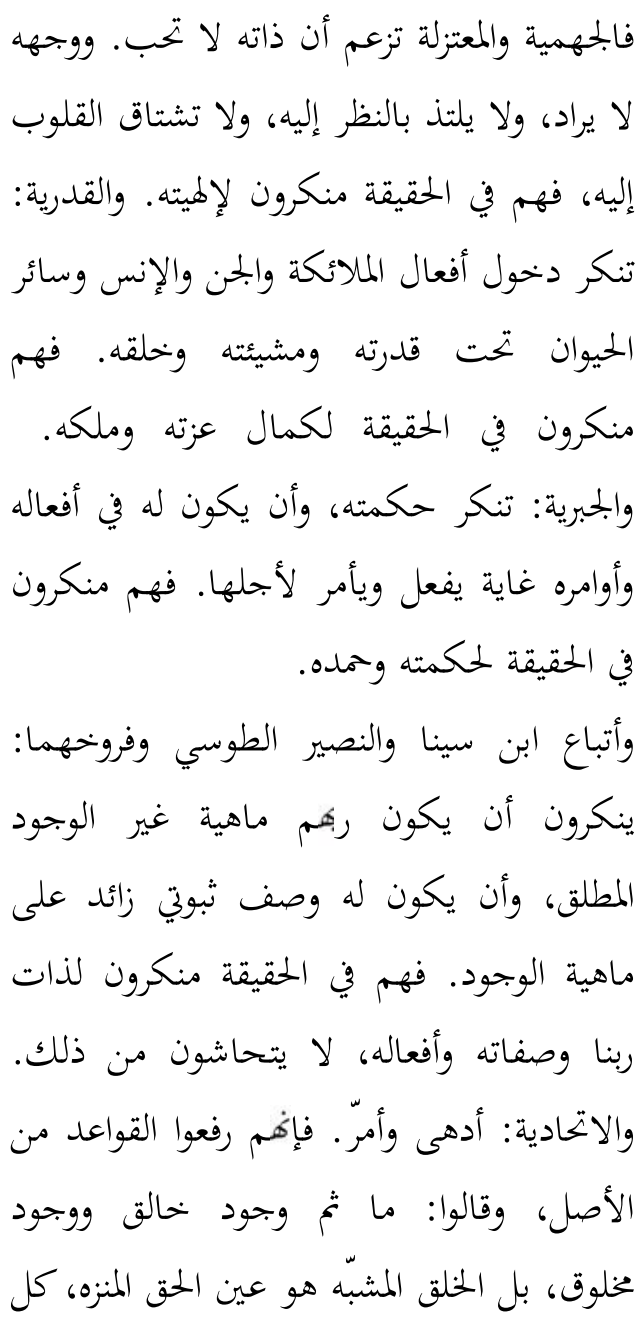

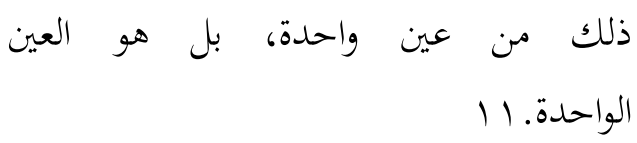

Dari sini nampak jelas, bahwa Ibnu Al-Qayyim menolak pandapatpendapat beberapa aliran teologi, seperti Jahmiyah, Mu'tazilah, Qadariyah, Jabariyah, Ibnu Sina dan lainnya.

d) Corak Tafsir Ibnu Al-Qayyim

Tafsir-tafsir Ibn al Qayyim nampaknya bercorak lughawi ijtima'iy. Corak lughawi-nya ditandai dengan pembahasan kata dari sudut bahasa, apakah itu makna dasar sebuah kata, derifasinya bahkan makna kata tersebut juga dibahas, di samping itu, Ibnu AlQayyim seringkali untuk menafsirkan suatu ayat ia menyertakan beberapa bait syi'ir, menyisipkan beberapa bait syi'ir untuk memperkuat penafsirannya.

Sedangkan corak ijtima'iy-nya ditandai dengan kecendrungan tafsirnya yang sangat responsif-reaktif terhadap perkembangan sosio-historis yang terjadi. Misalnya, pada bagian tafsirnya Ibn al-Qayyim menyatakan penolakannya terhadap beberapa paham keagamaan tertentu, seperti paham "Nafy al-Shifat" dari kelompok jahmiyah yang dipandangnya sebagai sesat.

Sedangkan pada bagian tafsirnya yang lain, Ibn al-Qayyim menyatakan kesetujuannya atau penerimaannya terhadap pandangan keagamaan ulamaulama tertentu, terutama gurunya, yaitu Ibnu Taimiyyah. Pada bagian tafsir lainnya Ibn al Qayyim al Jauziyah memperkenalkan wacana keagamaa baru yang mungkin dikembangkannya dalam rangka pembaharuan ummat 
islam. Di bidang tasawwuf misalnya, Ibn al-Qayyim menggagas beberapa pokok pemikiran yang dinilai oleh para ahli sebagai wacana pemikiran neo sufisme.

\section{Penutup}

Dari pemaparan di atas, dapat disimpulkan beberapa hal:

1. Kitab Tafsir al-Qayyim dan Badâi' al-Tafsir ini pada dasarnya bukanlah karya Ibnu Al-Qayyim sendiri, karena Ibnu Al-Qayyim tidak pernah menulis kitab tafsir. Kitab ini dikumpulkan oleh Yusri Al-Sayyid Muhammad, yang mana sebelumnya telah dirintis oleh Muhammad Uwais al Nadwi.

2. Kitab ini tidak mencakup seluruh penafsiran ayat al Quran dikarenakan kitab ini bukanlah merupakan tulisan yang sejak awal dimaksudkan sebagai kitab tafsir. Kitab ini mencakup 109 surat. Adapun surat yang tidak ditafsirkan dalam kitab ini adalah surat $\mathrm{Al}$ Qadr, Al Qari'ah, Al Fil, Quraisy dan Al Kautsar.

3. Tafsir Al-Qayyim ini berisikan multi-metode tafsir, ada yang berbentuk Tahliliy, Ijmali, Maudhu'I dan Muqaran.

4. Dalam menafsirkan AL-Quran, Ibn al-Qayyim tidak mengambil sumber tafsir kecuali tafsir yang bersumberkan pada nash al-Qur'an dan al-Sunnah, atau pada riwayatriwayat yang datang baik dari kalangan sahabat, tâbi'in maupun tâbi' tâbi'in, yang dikenal dengan al tafsir bi al ma'tsur.

5. Corak tafsir Ibn al-Qayyim alJauziyyah adalah Adabiy Ijtimaiy.

\section{Daftar Kepustakaan}

Ayazi, Muhammad Ali, T.th., Al Mufassirun Hayatuhum wa Manhajuhum, Tp: Markaz Tahqiqi 'Ilum Islami

Al Jauziyah, Ibnu Al-Qayyim, T.th., Badâi' al Fawâid, Beirut: Dâr Al Kitab Al 'Arabiy

Ibnu Katsir, Al Hafiz, 1986, Al Bidâyah wa Al Nihâyah, Beirut: Dâr Al Fikr

Muhammad, Yusri Al Sayyid, 1427 H, Badâi' al Tafsir, Saudi: Dâr Ibn Jauziyah

Al Mutawalli, Shabri, 1986, Minhaj Ahlus Sunnah fi Tafsir al Quran, Kairo: Dâr Al Tsaqafah

Al Nadwi, Muhammad Uwais, 1410 H, Al Tafsir al Qayyim, Beirut: Dâr wa Maktab al-Hilâl

Al Shafadi, Shalahuddin Khalil bin Ubaik, 1998, A'yân al 'Ashri wa A'wân al Nashri, Beirut: Dâr al Fikr 